\title{
25 (OH) Vitamin D level and Calcium/Phosphorus Metabolism Disorders in Patients Living with HIV in Abidjan
}

\author{
Lydie Boyvin ${ }^{1,2}$, Jeanne Armande Aké ${ }^{1,2}$, Kipré Laurent Séri $^{1,2}$ \\ Gervais Mélaine M'boh ${ }^{2}$, Adou Francis Yapo ${ }^{2}$ and Joseph Allico Djaman ${ }^{1,2^{*}}$ \\ ${ }^{1}$ Department of Clinical and Fundamental Biochemistry, Institut Pasteur of Cote d'Ivoire (IPCI), \\ 01 BP 490, Abidjan 01, Côte d'Ivoire. \\ ${ }^{2}$ Pharmacodynamics Laboratory of Biochemical, University Félix Houphouët-Boigny (UFHB), \\ 01 BP V34, Abidjan 01, Côte d'Ivoire.
}

Authors' contributions

This work was carried out in collaboration between all authors. Author LB wrote the protocol and wrote the first draft of the manuscript. Authors JAA and KLS supervised blood samples collection and managed the biological analyses of the study. Author GMM performed the final statistical analysis. Author AFY corrected the first draft of the manuscript. Author JAD designed the study, managed the literature searches and the final correction of the manuscript. All authors read and approved the final version of the manuscript.

Article Information

DOI: $10.9734 /$ IJBCRR/2017/34351

Editor(s):

(1) Fatih Oz, Food Engineering Department, Agriculture Faculty, Ataturk University, Turkey.

Reviewers:

(1) Germán Domínguez-Vías, University of Cádiz, Spain.

(2) Nagahito Saito, Takagi Hospital, Japan.

Complete Peer review History: http://www.sciencedomain.org/review-history/19597

Original Research Article

Received 24 $4^{\text {th }}$ May 2017

Accepted $13^{\text {th }}$ June 2017

Published $17^{\text {th }}$ June 2017

\section{ABSTRACT}

Aims: The present study was to evaluate the serum calcium level, phosphorus and $25(\mathrm{OH})$ vitamin D subjects during HIV infection; precisely in patients living with HIV (PLHIV).

Study Design: Prospective and experimental study, involving a cohort of blood samples from HIVnegative and positive subjects.

Place and Duration: The study was carried out in the clinical and fundamental biochemistry Department of the Institut Pasteur of Côte d'Ivoire from June 2014 to December 2014.

Methodology: A cohort of 220 samples from adult blood samples, comprising of 110 HIV negative 
controls and 110 samples from PLHIV subjects, were analyzed. After confirmation of HIV status (through an HIV rapid test) of subjects, CD4 lymphocytes were measured through flow cytometry analysis using an automated FacsCalibur ${ }^{\mathrm{TM}}$. Analysis of calcium and phosphorus electrolytes was performed on the Cobas Integra 400 Plus and $25(\mathrm{OH})$ vitamin D on the automated mini VIDAS, from the sera obtained from different blood samples from HIV positive and negative subjects.

Results: The identified disorders in the PLHIV were hypocalcemia $(P=0.0009)$ and hyperphosphoremia $(p<0.0001) .57 \%$ of PLHIV against $67 \%$ of the control subjects showed normal levels of $25(\mathrm{OH})$ vitamin $\mathrm{D}(\mathrm{P}>0.05)$.

Conclusion: We noticed a good level of $25(\mathrm{OH})$ Vitamin D reserve in PLHIV among more than $50 \%$ of PLHIV. Calcium and Phosphorous metabolism disorders observed in people living with HIV in Côte d'Ivoire are due to a deficiency of the active form $1,25(\mathrm{OH})_{2}$ vitamin D.

Keywords: $25(\mathrm{OH})$ Vitamin D; calcium; Côte d'Ivoire; HIV; phosphorus.

\section{ABBREVIATIONS}

$\begin{array}{lll}\text { AIDS } & : \begin{array}{l}\text { Acquired Immune Deficiency } \\ \text { Syndrome }\end{array} \\ \text { CaR } & : \text { Calcium Receptor } \\ \text { EDTA } & : \text { Ethylene diamine tetra acetic } \\ \text { FGF-23 } & : \text { Fibroblast growth factor } 23 \\ \text { IPCI } & : \text { Institut Pasteur of Côte d'Ivoire } \\ \text { PLHIV } & : \text { Patients Living with HIV } \\ \text { PN PEC } & \text { National Program on } \\ \text { PLHIV/ AIDS : } & \text { treatment management for } \\ & \text { People Living with HIV / AIDS } \\ \text { PTH } & : \text { Parathyroid hormone } \\ \text { VDR } & : \text { Vitamin D receptor } \\ \text { VITD } & : \text { Vitamin D }\end{array}$

\section{INTRODUCTION}

HIV uses nutrients, especially micronutrients (vitamins and minerals) in the body for its replication [1]. This causes long-term metabolic disorder [2]. Calcium and phosphorus metabolism are involved in the homeostasis of the human organism [3]. Its disorders are responsible for metabolic disorders [vitamin $\mathrm{D}$ deficiency, Parathyroid hormone (PTH)] [4]. Vitamin $\mathrm{D}$, fat-soluble vitamin is very essential to the body organism; it is involved in the maintenance of calcium and phosphorus homeostasis [5]. $25(\mathrm{OH})$ Vitamin $\mathrm{D}$ is the bulk storage form of vitamin $D$ in the body and is hydrolyzed in the kidney to 1-25dihydroxyvitamin $\mathrm{D}$, the active form of Vitamin $\mathrm{D}$ [6]. Indeed, many National and International Medical Societies recommend measuring 25 $(\mathrm{OH})$ vitamin $\mathrm{D}$ at least in any situation of bone fragility, in malabsorptions, in chronic kidney disease, in any phosphocalcic pathology, etc. [7]. In Côte d'Ivoire, HIV prevalence in the population is $3.7 \%$ [8]. Very few studies have been conducted concerning calcium phosphate metabolism and vitamin D during HIV infection. Evaluation of calcium and phosphorus levels during HIV infection is very important in order to assess the vitamin D status and to examine its concentration level in PLHIV. The main objective was to evaluate the calcium, phosphorus and 25 $(\mathrm{OH})$ vitamin $\mathrm{D}$ serum concentration levels in patients living with HIV compared to HIV negative (HIV-).

\section{MATERIALS AND METHODS}

The prospective and experimental study, casecontrol, involving a cohort of 110 adult HIV positive subjects (males and females) was conducted from June 2014 to December 2014. The blood samples used in the study came from the medical center of the Institut Pasteur of Côte d'Ivoire (IPCI) and the Community Health Center of Yopougon Toit-Rouge (Abidjan). The controls (110) consisted of HIV-negative subjects. However, HIV-positive pregnant women, elderly women 50 years and over were excluded from this study. Vitamin D supplement was excluded from the treatment given to the people living with HIV. The whole blood samples from HIV positive and negative subjects were collected into tubes without anticoagulant (dry tubes) and tube with ethylene diamine tetra acetic (EDTA) for measuring CD4+ T cells. Sera obtained after centrifugation at $3000 \mathrm{rev} / \mathrm{min}$ for 5 min from dry tubes were used for HIV serological tests and for the determination of calcium, phosphorus electrolytes and $25(\mathrm{OH})$ vitamin D.

\subsection{Biochemical Analysis}

After confirmation of HIV status of subjects participating through rapid HIV test DETERMINE [9] and GENIE II [10]. The CD4 cell count was carried out using flow cytometry technology 
(Facs Calibur) which follows the principle of the rapid analysis of particles (cells) in a movement that scroll to an inside of a sheath liquid, in front of a light beam to the laser beam [11]. Electrolyte parameters of calcium and phosphorus were performed on the Cobas Integra 400 Plus analyzer. The principle is based on the reaction of TRINDER = enzymatic method + colorimetric using a chromogen [12]. The deepness of the color is directly proportional to the concentration of the substances measured. The assay of the $25(\mathrm{OH})$ vitamin $\mathrm{D}$ was performed by combining the competitive enzyme linked immunosorbent assay to a final fluorescence detection (enzyme linked fluorescent Assay ELFA) on an automated immunoanalyzers "mini VIDAS" by Biomerieux France. The value of the fluorescence signal is inversely proportional to the concentration of antigen present in the blood sample. The reference values of $25(\mathrm{OH})$ Vitamin $\mathrm{D}$ are: Deficient (< $20 \mathrm{ng} / \mathrm{mL})$; Insufficient (20-29 $\mathrm{ng} / \mathrm{mL})$; Sufficient (30-100 $\mathrm{ng} / \mathrm{mL})$; Potentially toxic (> $100 \mathrm{ng} / \mathrm{mL})$ [13].

\subsection{Statistical Analysis}

The statistical analysis was performed using the Excel spreadsheet for calculating means and standard deviations, Student's t test for comparison of means and the Chi-square test for independence or dependence between two characters (significance threshold $\mathrm{P}<0.05 ; \mathrm{Cl}$ $95 \%)$.

\section{RESULTS}

\subsection{Epidemiology of HIV Infection in the Study Population}

Analyzing the 110 samples collected from PLHIV for the concentration level of $25 \mathrm{OH}$ VITD, Calcium and Phosphorus, women are more infected $(65 ; 59,09 \%)$ than men $(45 ; 40.91 \%)$. The average age of the study population was 37 \pm 1.59 years for PLHIV and $26 \pm 8.39$ years for HIV-controls $(P<0.0001)$ with a predominance of HIV-1 serotype (98/110; 89.09\%).

\subsection{Phosphorus, Calcium and $25(\mathrm{OH})$ Vitamin D Profiles}

The calcium mean values, in PLHIV were significantly lower $(2.08 \pm 2.27 \mathrm{mmol} / \mathrm{L})$ than in control subjects $(2.30 \pm 0.97 \mathrm{mmol} / \mathrm{L}) \quad(P=$ $0.0009)$. In contrast phosphorus mean values were significantly higher in people living with HIV $(2.13 \pm 4.69 \mathrm{mmol} / \mathrm{L})$ than in control subjects $(1.10 \pm 1.26 \mathrm{mmol} / \mathrm{L})(P<0.0001)$ (Table 1).

A deficiency of $25(\mathrm{OH})$ Vitamin D was observed in $43 \%$ of PLHIV and $33 \%$ of controls. While $57 \%$ of PLHIV and $67 \%$ of control showed normal levels of $25 \mathrm{OH}$ Vitamin D (Fig. 1).

Table 1. Average concentrations of calcium, phosphorus and $25(\mathrm{OH})$ Vitamin D in HIV patients and control subjects according to gender

\begin{tabular}{|c|c|c|c|c|c|c|}
\hline & \multicolumn{3}{|c|}{ Males } & \multicolumn{3}{|c|}{ Females } \\
\hline & PLIHIV & Control & P-values* & PLIHIV & Control & P-values* \\
\hline $\begin{array}{l}\text { Calcium } \\
(2.2-2.7 \mathrm{mmol} / \mathrm{L})\end{array}$ & $2.08 \pm 2.7$ & $2.25 \pm 1.3$ & 0.0225 & $2.10 \pm 3.7$ & $2.35 \pm 1.4$ & 0.0165 \\
\hline $\begin{array}{l}\text { Phosphorus } \\
(0.90-1.45 \mathrm{mmol} / \mathrm{L}) \\
25-\mathrm{OH}-\mathrm{VITD}\end{array}$ & $1.84 \pm 6.8$ & $1.03 \pm 0.92$ & 0.0004 & $2.42 \pm 6.2$ & $1.19 \pm 2.3$ & $<0.0001$ \\
\hline$(30-100 \mathrm{ng} / \mathrm{mL})$ & $36 \pm 2.83$ & $37 \pm 2.58$ & 0.75 & $31 \pm 1.91$ & $33 \pm 2.11$ & 0.62 \\
\hline
\end{tabular}

Table 2. Average concentrations level of calcium, phosphorus and $25(\mathrm{OH})$ Vitamin D in PLHIV according to $\mathrm{CD4}^{+}$count

\begin{tabular}{llllllll}
\hline $\begin{array}{l}\text { CD4+ } \\
\text { Range }\end{array}$ & $\begin{array}{l}\text { PLHIV } \\
\text { (N= 110) }\end{array}$ & \multicolumn{2}{c}{ Calcium } & \multicolumn{2}{c}{ Phosphorus } & \multicolumn{2}{c}{ 25 (OH) Vitamin D } \\
\cline { 3 - 8 } & & $\begin{array}{l}\text { Mean } \\
\text { concentration } \\
\text { (mmol/L) }\end{array}$ & $\begin{array}{l}\text { Chi2 } \\
\mathbf{P}^{*}\end{array}$ & $\begin{array}{l}\text { Mean } \\
\text { concentration } \\
\text { (mmol/L) }\end{array}$ & $\begin{array}{l}\text { Chi2 } \\
\mathbf{P}^{*}\end{array}$ & $\begin{array}{l}\text { Mean } \\
\text { concentration } \\
\text { (ng/mL) }\end{array}$ & $\begin{array}{l}\text { Chi2 } \\
\mathbf{P}^{*}\end{array}$ \\
\hline$>500$ & 26 & $1.98 \pm 5.39$ & 0.39 & $1.87 \pm 4.41$ & 0.17 & $31 \pm 5.5$ & 0.64 \\
$499-350$ & 29 & $2.10 \pm 4.71$ & 0.30 & $1.71 \pm 4.86$ & 0.25 & $33 \pm 7.0$ & 0.38 \\
$349-200$ & 33 & $1.98 \pm 4.18$ & 0.45 & $2.48 \pm 7.49$ & 0.35 & $32 \pm 11$ & 0.61 \\
$<200$ & 22 & $2.33 \pm 2.27$ & 0.32 & $2.90 \pm 14.46$ & 0.17 & $37 \pm 11$ & 0.41 \\
\hline \multicolumn{2}{r}{ * The difference is significance for $P<0.05$} & &
\end{tabular}


The average calcium values in PLHIV were lowered and were almost the same value for both sex, $2.08 \pm 2.7 \mathrm{mmol} / \mathrm{L}$ in men and $2.10 \pm 3.7$ $\mathrm{mmol} / \mathrm{L}$ in women respectively. However, with phosphorus (reference value $0.90-1.45 \mathrm{mmol} / \mathrm{L}$ ), the mean values were higher $2.42 \pm 6.2 \mathrm{mg} / \mathrm{L}$ in women with HIV than in men $1.84 \pm 6.8 \mathrm{mmol} / \mathrm{L}$. This increased value in women with HIV is highly significant compared to control subjects $(\mathrm{p}<$ 0.0001 ) (Table 1). The Mean values of $25 \mathrm{OH}$ Vitamin D in PLHIV is not significantly different from those of control subjects $(P>0.05)$ (Table 1).
The mean concentration values of calcium and phosphorus vary insignificantly according to the WHO classification of CD4 in PLHIV. However, the average values of $25 \mathrm{OH}$ Vitamin D in PLHIV vary not significantly $(P=0.77)$ according to the WHO classification of CD4 count (Table 2).

The average values of phosphorus in PLHIV females and males increased not significantly $(P$ $>0.05)$ with decreased levels of CD4 range according to WHO classification count (Tables $3 a$ and $3 b$ ).

Table 3a. Concentrations of calcium, phosphorus and $25(\mathrm{OH})$ Vitamin D in HIV-infected women according to $\mathrm{CD}^{+}$count

\begin{tabular}{|c|c|c|c|c|c|c|c|}
\hline \multirow{2}{*}{$\begin{array}{l}\text { CD4+ } \\
\text { Range }\end{array}$} & \multirow{2}{*}{$\begin{array}{l}\text { PLHIV } \\
\text { female } \\
(n=73)\end{array}$} & \multicolumn{2}{|c|}{ Calcium } & \multicolumn{2}{|c|}{ Phosphorus } & \multicolumn{2}{|c|}{$25(\mathrm{OH})$ Vitamin D } \\
\hline & & $\begin{array}{l}\text { Mean } \\
\text { concentration } \\
\text { (mmol/L) }\end{array}$ & $\begin{array}{l}\text { Chi2 } \\
\mathrm{P}^{\star}\end{array}$ & $\begin{array}{l}\text { Mean } \\
\text { concentration } \\
\text { (mmol/L) }\end{array}$ & $\begin{array}{l}\text { Chi2 } \\
P^{\star}\end{array}$ & $\begin{array}{l}\text { Mean } \\
\text { concentration } \\
(\mathrm{ng} / \mathrm{mL})\end{array}$ & $\begin{array}{l}\text { Chi2 } \\
P^{\star}\end{array}$ \\
\hline$>500$ & 18 & $2.36 \pm 2.83$ & 0.35 & $1.94 \pm 4.94$ & 0.15 & $29 \pm 4.45$ & 0.54 \\
\hline $499-350$ & 18 & $2.29 \pm 8.12$ & 0.30 & $1.91 \pm 2.10$ & 0.20 & $32 \pm 5.98$ & 0.48 \\
\hline $349-200$ & 15 & $1.97 \pm 2.25$ & 0.43 & $2.58 \pm 3.82$ & 0.34 & $26 \pm 9.51$ & 0.60 \\
\hline$<200$ & 22 & $1.84 \pm 1.53$ & 0.31 & $3.42 \pm 4.57$ & 0.16 & $37 \pm 11.03$ & 0.45 \\
\hline
\end{tabular}

Table 3b. Concentrations of calcium, phosphorus and $25(\mathrm{OH})$ Vitamin D in HIV-infected men according to $\mathrm{CD}^{+}$count

\begin{tabular}{|c|c|c|c|c|c|c|c|}
\hline \multirow{2}{*}{$\begin{array}{l}\text { CD4+ } \\
\text { Range }\end{array}$} & \multirow{2}{*}{$\begin{array}{l}\text { PLHIV } \\
\text { male } \\
(n=37)\end{array}$} & \multicolumn{2}{|c|}{ Calcium } & \multicolumn{2}{|c|}{ Phosphorus } & \multicolumn{2}{|c|}{25 (OH) Vitamin D } \\
\hline & & $\begin{array}{l}\text { Mean } \\
\text { concentration } \\
\text { (mmol/L) }\end{array}$ & $\begin{array}{l}\text { Chi2 } \\
P^{\star}\end{array}$ & $\begin{array}{l}\text { Mean } \\
\text { concentration } \\
\text { (mmol/L) }\end{array}$ & $\begin{array}{l}\text { Chi2 } \\
P^{\star}\end{array}$ & $\begin{array}{l}\text { Mean } \\
\text { concentration } \\
(\mathrm{ng} / \mathrm{mL})\end{array}$ & $\begin{array}{l}\text { Chi2 } \\
\mathrm{P}^{\star}\end{array}$ \\
\hline$>500$ & 7 & $2.14 \pm 5.57$ & 0.30 & $1.19 \pm 1.08$ & 0.17 & $34 \pm 7.21$ & 0.50 \\
\hline $499-350$ & 11 & $2.19 \pm 2.83$ & 0.35 & $1.61 \pm 7.78$ & 0.40 & $35 \pm 16.78$ & 0.45 \\
\hline $349-200$ & 15 & $2.12 \pm 3.41$ & 0.45 & $2.26 \pm 4.97$ & 0.45 & $38 \pm 11.80$ & 0.64 \\
\hline$<200$ & 4 & $2.29 \pm 6.41$ & 0.32 & $3.07 \pm 4.09$ & 0.15 & $37 \pm 0.07$ & 0.42 \\
\hline
\end{tabular}

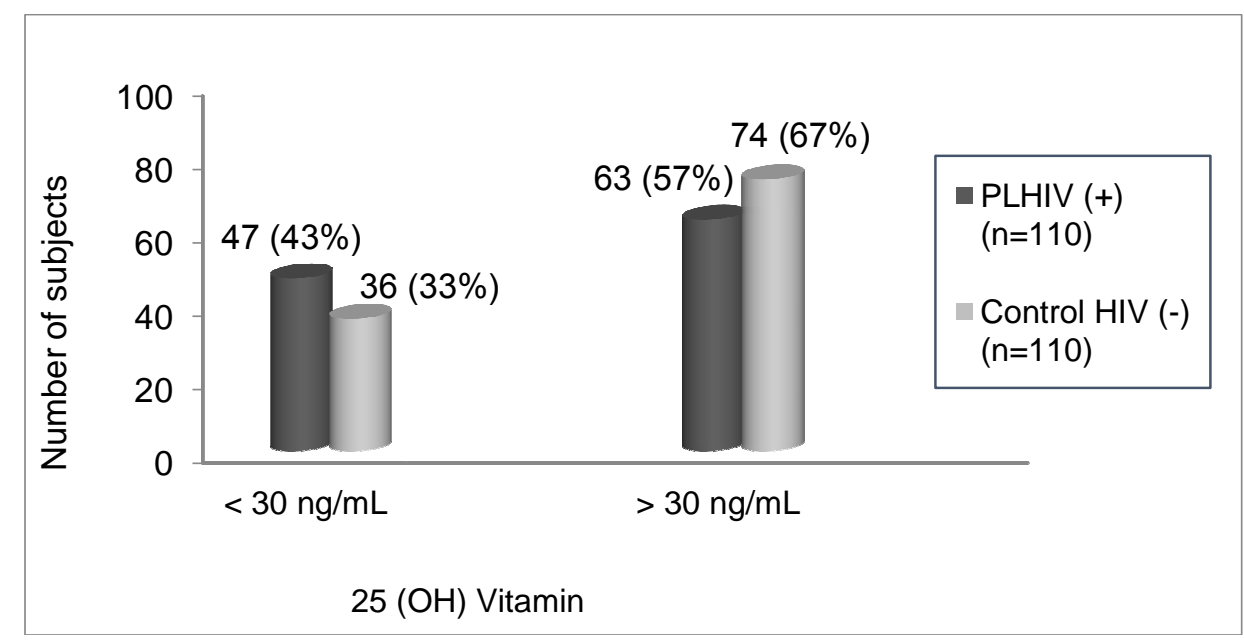

Fig. 1. Distribution of people living with HIV (PLHIV) according to their vitamin D profile 


\section{DISCUSSION}

Hypocalcemia and hyperphosphatemia observed in patients living with HIV showed a disorder in mineral metabolism. Indeed, hypocalcemia is due to a deficiency of 1,25-dihydroxy-vitamin-D3 caused by decreases in secretion of parathyroid hormone and also in activation of the extracellular calcium receptor (CaR) [14]. Therefore, there will be no distribution of calcium from the cell into the blood [15]. The inflammatory process due to virus replication causes hypocalcemia [16]. Hyperphosphatemia is due to the low serum parathyroid hormone (PTH) level and the inhibitory action of the FGF23 on the $\alpha-1$-hydroxylase. There will be no phosphate reabsorption in the proximal tubule [15]. However, certain antiviral molecules involving nucleotide analogs to nucleoside analogues can cause damage and kidney dysfunction, which leads to the reduction of the phosphorus filtration rate in the kidney thus raising its level in the blood serum [17].

Sufficiency in $25(\mathrm{OH})$ vitamin $D$ reserves observed in our study could be explained due to the fact that Côte d'Ivoire is a tropical country with heavy sunshine, the major intakes pathway of vitamin $D$ to the body is through skin synthesis $[18,19]$. The deficiency cases observed in control subjects may be due to the consumption of diets poor in vitamin $D$, since its supply has two sources (food and synthesis); or by using sunscreens with a protective factor of 8 or higher and renal and/or hepatic pathologies such as cholestatic hepatitis [20,21].

This study showed calcium and phosphorus disorders and good quantity of $25(\mathrm{OH})$ vitamin D reserves in half of HIV-infected subjects. This is due to abnormality in the nuclear Vitamin $D$ receptor (VDR). The second hydroxylation of 25 $(\mathrm{OH})$ vitamin $\mathrm{D}$ into the active form $1,25-(\mathrm{OH})_{2}$ vitamin D3 via VDR will not be performed. In addition, an alteration in the recognition of $1,25(\mathrm{OH})_{2} \mathrm{D}$ by its receptor can also cause vitamin $\mathrm{D}$ deficiency, metabolic bone disease, and accompanying biochemical abnormalities. This would cause disorders in the calcium and phosphorus metabolism [22].

However, women present more disorders of the metabolism of calcium and phosphorus and the $25(\mathrm{OH})$ vitamin $\mathrm{D}$ concentration are lowered as well as normal. It is true that these disorders of phosphocalcic metabolism observed in HIV infection are due to a deficiency of $1,25(\mathrm{OH})_{2}$ vitamin $\mathrm{D}$, in addition, studies have shown that HIV-infected women suffer from osteopenia, there is a dissociation between lower markers of bone formation rate and increased bone resorption expressed as elevated calcium excretion. This study concluded that the decreased levels of $1.25(\mathrm{OH})_{2} \mathrm{D}$ could contribute to a negative calcium balance and inhibition of the formation of bone [23].

Furthermore, there is no relationship between the level of calcium and phosphorus metabolism disorders, $25(\mathrm{OH})$ vitamin $\mathrm{D}$ and the degree of immune suppression [24]. Concerning the relationship of vitamin $D$ to HIV viral load, and CD4+ $T$ cells count, a cross-sectional study in a cohort of 112 HIV infected adults has been evaluated by Bearden et al. [25]. The obtained outcome showed no association between $25(\mathrm{OH}) \mathrm{D}$ and $1,25(\mathrm{OH})_{2} \mathrm{D}$ levels and CD4 cell count.

\section{CONCLUSION}

Calcium and phosphorus metabolism disorders observed during HIV infection is due to a deficiency of $1,25(\mathrm{OH})_{2}$ vitamin $\mathrm{D}$. Therefore, further study on parathyroid hormone, calcitonin and on the mechanism of action of vitamin $D$ and its nuclear receptors is required. The serum calcium and phosphorus level monitoring are very important before and during antiretroviral treatment to prevent bone complications.

\section{ETHICAL STATEMENT AND CONSENT}

The study was conducted in accordance with the Helsinki Declaration 2000 on HIV and AIDS research conducted in poor countries and to the local legislation of the national program on treatment management for People Living with HIV / AIDS (Decree No. 411 of December 23, 2001).

Informed consent was obtained from patients for the use of their blood for research purpose after completing the standard analyzes prescribed by their doctor.

\section{COMPETING INTERESTS}

Authors have declared that no competing interests exist. 


\section{REFERENCES}

1. Shin $\mathrm{DH}$, Martinez SS, Parsons $M$, Jayaweera DT, Campa A, Baum MK. Relationship of oxidative stress with HIV disease progression in $\mathrm{HIV} / \mathrm{HCV}$ coinfected and HIV Mono-infected Adults in Miami. Intern J Biosci Biochem Bioinform. 2012;2:217-223.

2. Lake JE, Currier JS. Metabolic disease in HIV infection. Lancet Infect Dis. 2013;13: 964-975.

3. Hariri A, Mount DB, Rastegar A. Disorders of calcium, phosphate, and magnesium metabolism. In: Mount D, Sayegh $\mathrm{MH}$, Singh AK editors. Core concepts in the disorders of fluid, electrolytes and acidbase balance. New York: Springer US. 2013;103-146.

4. Zanchi A, Cherpillod A, Pitteloud N, Burnier M, Pruijm M. Insuffisance rénale et diabète: Les précautions à prendre. Forum Med Suisse. 2014;14(Suppl 6):100104.

5. Hoenderop J, Nilius B, Bindels R. Calcium absorption across epithelia. Physiol Rev. 2005;85:373-422.

6. Heaney RP, Horst RL, Cullen DM, Armas LA. Vitamin D3 distribution and status in the body. J Am Coll Nutr. 2009;28:252256.

7. Boyvin L, M'boh G, Ake-Edjeme A, Soumahoro-Agbo MK, Séri K L, Djaman J. Serum level of two antioxidant vitamins ( $A$ and $\mathrm{E}$ ) in Ivorian (Côte d'Ivoire) people living with human immunodeficiency virus. Ann Biol Res. 2013;4:48-54.

8. Gürtler LG, Hauser $\mathrm{PH}$, Eberle J, von Brunn A, Knapp S, Zekeng L, et al. A new subtype of human immunodeficiency virus type 1 (MVP-5180) from Cameroon. J Virol. 1994;68:1581-5.

9. Nkengasong JN, Maurice C, Koblavi S. Evaluation of serial and parallel serologic testing algorithms in Abidjan, Ivory Cost. AIDS Res Hum Retroviruses. 1999;13: 109-117.

10. Ormerod MG, Editor, Flow cytometry: A Practical Approach, 3 ed. Oxford: OUP. 2000;276.

11. Deyhimi F, Arabieh M, Parvin L. Optimizatoin of the Emerson-Trinder enzymatic reaction by response surface methodology. Biocatal Biotransformation. 2006;24:263-271.
12. Holick MF. Vitamin D status: Measurement, interpretation, and clinical application. Ann Epidemiol. 2009;19:73-78.

13. Arpadi SM, McMahon DJ, Abrams EJ, Bamji M, Purswani M, Engelson ES, et al. Effect of supplementation with cholecalciferol and calcium on 2-y bone mass accrual in HIV-infected children and adolescents: A randomized clinical trial. Am J Clin Nutr. 2012;95:678-685.

14. Civiteli R, Ziambaras K. Calcium and phosphore homeostasis: Concerted interplay of new regulator. J Endocrinol Invest. 2011;34:3-7.

15. Moges B, Amare B, Yabutani T, Kassu A. HIV associated hypocalcaemia among diarrheic patients in northwest Ethiopia: A cross sectional study. BMC Public Health. 2014;14:679.

16. Essig M, Duval X, Kaied F A, lordache L, Gervais $A$, Longuet $P$, et al. Is phosphatémie the best tool to monitor renal tenofovir toxicity? J Acquir Immune Defic Syndr. 2007;46:256-258.

17. Vieth R, Bischoff-Ferrari H, Boucher BJ, Dawson-Hughes B, Garland CF, Heaney $\mathrm{RP}$, et al. The urgent need to recommend an intake of vitamin $D$ that is effective. Am J Clin Nutr. 2007;85(Suppl 3):649-650.

18. Kim JH, Gandhi V, Psevdos G Jr, Espinoza F, Park J, Sharp V. Evaluation of Vitamin D Levels among HIV-Infected Patients in New York City. AIDS Res Hum Retroviruses. 2012;28:235-241.

19. Norval M, Coussens AK, Wilkinson RJ, Bornman L, Lucas RM, Wright CY. Vitamin $D$ status and its consequences for health in South Africa. Int J Environ Res Public Health. 2016;13(10):1019.

DOI: 10.3390/ijerph13101019

20. Holick MF. Vitamin D: importance in the prevention of cancers, type 1 diabetes, heart disease, and osteoporosis. Am J Clin Nutr. 2004;79(3):362-71.

21. Anonymous. Food and nutrition board, institute of medicine, vitamin $\mathrm{d}$. dietary reference intakes: Calcium, Phosphorus, Magnesium, Vitamin D, and Fluoride, Washington DC: National Academic Press. 1999;250-287.

22. Dougherty KA, Schall JI, Zemel BS, Tuluc F, Hou X, Rutstein RM, et al. Safety and efficacy of high-dose daily vitamin d3 supplementation in children and young adults infected with human 
immunodeficiency virus. J Pediatric Infect Dis Soc. 2014;3(4):294-303.

23. Teichmann J, Stephan E, Lange U, Discher T, Friese G, Lohmeyer J, et al. Osteopenia in HIV-infected women prior to highly active antiretroviral therapy. J. Infect. 2003;46(4):221-7.

24. Souberbielle JC, Deschenes G, Fouque D, Groussin L, Guggenbuhl P, Jean G, et al. Recommendations for the measurement of blood 25-OH vitamin D. Ann Biol Clin. 2016;74(1):7-19.

25. Bearden A, Abad C, Gangnon, R, Sosman JM, Binkley N, Safdar NJ. Cross- sectional study of vitamin D levels, immunologic and virologic outcomes in HIV- infected adults. Clin Endocrinol Metab. 2013;98:17261733.

(C) 2017 Boyvin et al.; This is an Open Access article distributed under the terms of the Creative Commons Attribution License (http://creativecommons.org/licenses/by/4.0), which permits unrestricted use, distribution, and reproduction in any medium, provided the original work is properly cited.

Peer-review history:

The peer review history for this paper can be accessed here: http://sciencedomain.org/review-history/19597 